Nig. J. Biotech. Vol. 38 (1) : 61-67 (June 2021)

ISSN: 01891731

Available online at

http://www.ajol.info/index.php/njb/index

and www.biotechsocietynigeria.org

DOI: https://dx.doi.org/10.4314/njb.v38i1.7

\title{
Effects of cowpea ( Vigna unguiculata L. Walp.) as a Live mulch on weed management in maize cropping
}

\author{
Woghiren", A. I., Awodoyin', R. O., Antiabongc, C. I., Ngonadid, E. N., \\ Jeminiwaa, O. R., and Olaoti-Laaro, , S. O \\ a Present Address: Department of Forest Conservation and Protection, Forestry Research \\ Institute of Nigeria, P.M.B 5054, Jericho, Ibadan, Nigeria. \\ ${ }^{\mathrm{b}}$ Department of Crop Protection and Environmental Biology, University of Ibadan, Ibadan, \\ Nigeria \\ c Center of Sustainable Development University of Ibadan, Ibadan, Nigeria \\ ${ }^{d}$ Department of Crop Science and Horticulture, Chukwuemeka Odumegwu Ojukwu University, \\ Igbariam, Nigeria.
}

\begin{abstract}
Weed interference is a major constraint in maize cultivation. Living mulch as an alternative weed control strategy has been established to be environmentally safe but has not been widely used in maize cultivation. The aim of this research was to evaluate the weed management attributes of Vigna unguiculata in maize cropping. A field study was carried out in the crop garden of the Department of Crop Protection and Environmental Biology, University of Ibadan, Nigeria. The treatments were maize interplanted with Cowpea at 20,000 (M1), 30,000 (M2), 40,000 (M3) plants/hectare, hoe weeding (M4), weedy check (M5) and Primextra-2.5 L/ha (M6). The treatments were arranged in randomized complete block design, each replicated four times. Weed Dry Weight (WDW) and Weed Control Efficiency-WCE (\%) were calculated following standardized methods. Data were analysed using descriptive statistics and ANOVA at $a_{0.05}$. The treatment plots were dominated by weed species in the Asteraceae, Fabaceae and Poaceae families. The M5 accounted for the highest WDW (126.30 g). The WCE was highest in M3 (94.8\%) and least in M5 $(66.4 \%)$. Maize and cowpea interplant at 40,000 plants/ hectare suppressed weed. Hence, cowpea is an ideal weed suppressant and can be inter-planted as a cover crop in maize cropping systems.
\end{abstract}

Keywords: Weed suppressant, Cover crop, Weed control efficiency, Cowpea.

* Correspondence Author: woghiren.ai@frin.gov.ng; +2348055268286

Introduction

Over the years, farmers have been faced with challenges of weed infestation that needs to be addressed because it negates optimum crop yield. The presence of weed seeds could be due to the presence of weeds in the soil seed bank or non-native seeds brought in with crops. Weed is an important pest of crops that has the potential of reducing crop yield if not adequately managed. In Nigeria, maize is currently an essential cereal crop for a good number of people; however, weed infestation limits its continuous production (IITA, 2012). Severe weed infestations have resulted in up to $89 \%$ loss in maize yield (Imoloame and Omolaiye, 2017).

Chemical herbicides do work, but croplands end up having weeds that are resistant to these herbicides, hence the need to adapt integrated weed management which includes cover crops. Over reliance on chemical herbicide brings about numerous ecological and 
crop management problems that have deleterious effects on the health of the ecosystem. Soil void of mulch is usually prone to problems such as wearing of top soil, fertilizer and pesticide runoff into underground and surface waters. The use of intensive fallow systems that are cost effective and environmentally friendly using promising leguminous cover crops could proffer solution to these problems (Awodoyin and Ogunyemi, 2005).

The reduction of weed incidence in maize through cover crop interplanting is dependent on a number of factors, including manipulation of plant arrangement, planting and interplant species, fertilizer doses and period of assessment. Sown fallow or planted fallow can act as weed-break by preventing the sprouting of seeds and establishment of weed seedlings. Cover crops of beneficial features should not only have the capacity to cover the soil expeditiously, it must also be able to smother weeds swiftly and bring about a reduction in the use of herbicides (Woghiren and Awodoyin, 2018). Weed control had remained the highest time consuming operation of all the cultural practices in crop production in Nigeria. The growing of live mulches in the midst of arable crops simultaneously has great possibility of reducing man-hour used on weed control and the amount spent on weed management in addition to maximizing return (Weber et al., 2017).

Cowpea (Vigna unguiculata) is an
extensively cultivated, stress-resilient leguminous crop in Sub-Saharan Africa. Cowpea can generate a lot of biomass while also fixing a lot of nitrogen from the air. Cowpea has already been recognized as an excellent weed smothering cover crop (Woghiren and Awodoyin, 2018). It is essential to assess its preferred planting density to effectively suppress weeds in the maize cropping system. This study aimed at evaluating the various densities of cowpea that would enhance weed suppression in the maize field.

\section{Materials and Methods}

The experiment was carried out in the Crop garden of the Department of Crop Protection and Environmental Biology, University of Ibadan, (Latitude $7^{\circ} 27^{\circ} \mathrm{N}$; Longitude $3^{\circ} 53^{`} \mathrm{E}$; Elevation $218 \mathrm{~m} \mathrm{ASL}$ ), Nigeria. The field site was cleared manually with cutlasses and hoes and soil samples were collected by hand auger to determine physicochemical parameters analysis. The soil was loamy sand (sand-796.0, silt-136.0 and clay-68.0 g/kg), slightly acidic (pH-6.5), low in organic carbon (1.6\%) and low in total nitrogen content $(0.2 \mathrm{~g} / \mathrm{kg})$ (Table 1$)$. The study was a Randomized Complete Block Design (RCBD) with six treatments and four replicates. The experimental plot dimension was $19.4 \mathrm{~m} \times 13.5$ $\mathrm{m}$ which resulted in an area of $262 \mathrm{~m}^{2}$. Each replicate had a dimension of $2.5 \mathrm{~m} \times 1.6 \mathrm{~m}$ with an alley of $0.5 \mathrm{~m}$ between two blocks.

Three seeds of maize (DTMA - Y - STR) 60 days maturing variety, were sown on flat at a spacing of $0.80 \mathrm{~m} \times 0.50 \mathrm{~m}$. In the maize herbicide plots, primextra gold herbicide was applied (2.5 L/ha) to the experimental plots immediately after sowing. Maize plants were thinned to two (2) plants, two weeks after sowing (WAS), to give a plant population of 50,000 plants / ha. Two seeds of Vigna unguiculata were sown in between maize inter row $(0.40 \mathrm{~m})$ and later thinned at two weeks to one plant per stand. The M1 $(20,000$ cowpea plants per hectare) treatment were sown in between maize alleys at a spacing of $0.62 \mathrm{~m}$. The M2 (30,000 cowpea plants per hectare) treatment was planted in the maize alley at $0.41 \mathrm{~m}$. The M3 (40,000 cowpea plants per hectare) treatment was sown in the maize alley at a spacing of $0.31 \mathrm{~m}$. The intra-row spacing for the cover crops are indicated in Table 2. While the sole maize (hoe-weeded, weedy all through and herbicide) control treatment, were sown at a distance of $0.80 \mathrm{~m}$ wide inter row and $0.50 \mathrm{~m}$ intra row spacing. The treatment plots had one weeding regime which was at 3 WAS, with the exception of the weedy and the herbicide control, which were weedy throughout the study.

Table 1: Soil Analysis of the Experimental Soil

\begin{tabular}{lc}
\hline Properties & Values \\
\hline $\mathrm{pH}\left(\mathrm{H}_{2} \mathrm{O}\right)$ & 6.5 \\
Organic carbon $(\mathrm{g} / \mathrm{kg})$ & 16.30 \\
Total $\mathrm{N}(\mathrm{g} / \mathrm{kg})$ & 2.00 \\
Available $\mathrm{P}(\mathrm{mg} / \mathrm{kg})$ & 15 \\
\hline
\end{tabular}




\begin{tabular}{lc}
\hline Exchangeable base $(\mathrm{cmol} / \mathrm{kg})$ & \\
K (Potassium) & 0.3 \\
Physical properties $(\mathrm{g} / \mathrm{kg})$ & 796.0 \\
Sand & 136.0 \\
Silt & 68.0 \\
Clay & Loamy Sand \\
Textural classification & \\
\hline
\end{tabular}

Table 2: Treatments Combinations for Experimental Plots

\begin{tabular}{lcccc}
\hline Treatments & $\begin{array}{l}\text { Cover } \\
\text { Density }\end{array}$ & Crop & \multicolumn{2}{l}{ Planting Spacing } \\
\cline { 3 - 5 } Crops Combinations & $\begin{array}{l}\text { (Number } \\
\text { Plants / ha) }\end{array}$ & of & Maize & Cover Crops \\
& 20,000 & $0.5 \mathrm{~m} \times 0.8 \mathrm{~m}$ & $0.62 \mathrm{~m} \times 0.8 \mathrm{~m}$ \\
\hline Maize + Cowpea (M1) & 30,000 & $0.5 \mathrm{~m} \times 0.8 \mathrm{~m}$ & $0.41 \mathrm{~m} \times 0.8 \mathrm{~m}$ \\
Maize + Cowpea (M2) & 40,000 & $0.5 \mathrm{~m} \times 0.8 \mathrm{~m}$ & $0.31 \mathrm{~m} \times 0.8 \mathrm{~m}$ \\
Maize + Cowpea (M3) & - & $0.5 \mathrm{~m} \times 0.8 \mathrm{~m}$ & - \\
Hoe weeding (M4) & - & $0.5 \mathrm{~m} \times 0.8 \mathrm{~m}$ & - \\
Weedy check (M5) & - & $0.5 \mathrm{~m} \times 0.8 \mathrm{~m}$ & - \\
Primextra- 2.5 L/ha (M6) & & & \\
\hline
\end{tabular}

Note: Maize population per hectare $=50,000$ plants $/$ ha

\section{Data Collection}

The weed species were enumerated at the physiological maturity of maize (60 DAS). Two $25 \mathrm{~cm} \times 25 \mathrm{~cm}$ quadrats were randomly laid within each plot. The weeds rooting within the quadrat were identified to species level and counted using a flora handbook by Akobundu and Agyakwa (1987). The species that were not identified on the field were kept in a wooden press and taken to UI herbarium in the Department of Botany, University of Ibadan for identification. The weed samples were ovendried at $80^{\circ} \mathrm{C}$ to a constant weight and weighed for dry matter content. The true extent of weed reduction caused by weed control treatment is

\section{Results}

Floristic Enumeration of the Different Cowpea population in maize Cropping

Maize + Cowpea (20,000 plants / ha) - M1

A total of nineteen plants from

thirteen families was listed. Sesbania pachycarpa dominated with the highest Relative Importance Value (RIV) of $24.33 \%$ (Table 3 ). Brachiaria deflexa and Indigofera hirsuta followed with RIV of $13.84 \%$ and $13.79 \%$ respectively. Species with low RIV includes Corchorus olitorius and Dactyloctenium aegyptium which had denoted by weed control efficiency (WCE). It was calculated using the Mani et al. (1973) methodology and stated in percentage; WCE $(\%)=$ Dry weight of weeds in un-weeded control - Dry weight of treatment plot $\times 100$

Dry weight of weed in un weeded control

The compiled weed floristic information was evaluated using Paleontological Statistical Software (PAST, Version 2.01) of Hammer et al. (2001). The Relative Density (RD), Relative Frequency (RF) and Relative Importance Value (RIV) of floral species were calculated (Awodoyin and Olubode, 2009). 


\begin{tabular}{|c|c|c|c|c|c|c|c|c|}
\hline $\mathrm{S} / \mathrm{N}$ & Species name & Family & M1 & M2 & M3 & M4 & M5 & M6 \\
\hline 1 & Ageratum conyzoides Linn. & Asteraceae & 7.45 & 33.82 & 34.21 & 35.38 & 5.52 & 36.78 \\
\hline 2 & Amaranthus spinosus Linn. & Amaranthaceae & 0.74 & - & - & 1.60 & - & - \\
\hline 3 & Boerhavia diffusa Linn. & Nyctaginaceae & 5.41 & 5.22 & 6.01 & 7.56 & 4.63 & 4.36 \\
\hline 4 & Brachiaria deflexa (Schumach) Robyns & Poaceae & 13.84 & 20.18 & 18.10 & 19.22 & 17.30 & 33.46 \\
\hline 5 & Celosia argentea Linn. & Amaranthaceae & - & - & - & - & 2.15 & - \\
\hline 6 & Corchorus olitorius Linn. & Malvaceae & 0.68 & - & 1.74 & 0.77 & 3.79 & 1.31 \\
\hline 7 & Cleome viscosa Linn. & Capparidaceae & - & - & - & - & 1.36 & - \\
\hline 8 & Dactyloctenium aegyptium (L.) Willd. & Poaceae & 0.68 & - & - & 0.77 & - & 1.31 \\
\hline 9 & Desmodium scorpiurus (Swartz) Desvaux & Fabaceae & 3.25 & 7.60 & 8.34 & 6.70 & 14.73 & 5.81 \\
\hline 10 & Euphorbia heterophylla Linn. & Euphorbiaceae & 5.28 & 6.08 & 7.35 & 4.88 & 15.29 & 10.16 \\
\hline 11 & Euphorbia hirta Linn. & Euphorbiaceae & 4.06 & 4.36 & 3.30 & 3.78 & 1.07 & - \\
\hline 12 & Indigofera hirsuta Linn. & Fabaceae & 13.79 & 2.27 & - & 2.51 & 2.15 & 2.76 \\
\hline 13 & Ipomoea repens (L.) Poiret. & Convolvulaceae & 0.74 & 1.51 & 0.97 & - & - & - \\
\hline 14 & Ludwigia decurrens (DC.) Walter & Onagraceae & 1.22 & 2.34 & - & 2.51 & 1.07 & 1.31 \\
\hline 15 & Mimosa diplotricha C. Wright. & Fabaceae & - & - & - & - & 1.64 & - \\
\hline 16 & Mitracarpus villosus (Sw.) DC. & Rubiaceae & 6.02 & 3.46 & 2.71 & 4.12 & - & 1.45 \\
\hline 17 & Momordica charantia Linn. & Cucurbitaceae & - & - & 0.87 & - & - & - \\
\hline 18 & Panicum maximum Jacq. & Poaceae & - & - & - & - & 2.43 & - \\
\hline 19 & Phyllanthus amarus Schumach & Phyllanthaceae & 4.46 & 2.27 & 1.84 & - & 1.64 & 1.31 \\
\hline 20 & Portulaca oleracea Linn. & Portulacaceae & 1.62 & 2.99 & 2.13 & 2.94 & 2.43 & - \\
\hline 21 & Sesbania pachycarpa sensu auct./DC. & Fabaceae & 24.33 & - & 0.97 & - & 4.07 & - \\
\hline 22 & Talinum fructicosum (L.) Juss. & Talinaceae & 0.74 & 0.76 & 0.87 & 0.77 & 3.50 & - \\
\hline 23 & Tithonia diversifolia (Hemsl.) A. Gray. & Asteraceae & - & - & - & - & 9.26 & - \\
\hline 24 & Tridax procumbens Linn. & Asteraceae & 3.25 & 6.39 & 7.90 & 6.48 & 5.98 & - \\
\hline 25 & Vigna unguiculata (L.) Walp. & Fabaceae & 2.43 & 0.76 & 2.71 & - & - & - \\
\hline
\end{tabular}

Table 3: Relative Importance Value (\%) for Weeds Sampled Within the Different Treatments in Maize Field in Ibadan, Nigeria ( $\mathrm{n}=8$ )

NOTE: $M 1=$ Maize (50,000 plants/ha) + Cowpea (20,000 plant/ha) ; M2 = Maize (50,000 plants/ha) + Cowpea (30,000 plant/ha); M3 = Maize (50,000 plants/ha) + Cowpea (40,000 plants /ha); M4 = Hoe weeding (Maize (50,000 plants/ha); M5 = Weedy Check (50,000 plants/ha); M6 = Primextra -2.5 L/ha (50,000 plants/ha) 
Table 4: Diversity indices of herbaceous plants enumerated on maize plot in Ibadan, Nigeria

\begin{tabular}{llrcc}
\hline Treatment & Taxa_S & Shannon $\_H$ & Evenness $\mathrm{e}^{\wedge} \mathrm{H} / \mathrm{S}$ & Dominance _ D \\
\hline M1 & 19 & 1.65 & 0.29 & 0.30 \\
M2 & 15 & 1.51 & 0.30 & 0.34 \\
M3 & 16 & 1.58 & 0.30 & 0.32 \\
M4 & 15 & 1.44 & 0.28 & 0.38 \\
M5 & 19 & 2.42 & 0.59 & 0.12 \\
M6 & 11 & 1.19 & 0.30 & 0.39 \\
\hline
\end{tabular}

NOTE: $M 1=$ Maize (50,000 plants/ha) + Cowpea (20,000 plant/ha) $;$ M2 $=$ Maize (50,000 plants/ha) + Cowpea (30,000 plant/ha); M3 = Maize (50,000 plants/ha) + Cowpea (40,000 plants /ha); M4 = Hoe weeding (Maize (50,000 plants/ha); M5 = Weedy Check (50,000 plants/ha); M6 = Primextra - $2.5 \mathrm{~L} / \mathrm{ha}$ (50,000 plants/ha)

RIV values of $0.68 \%$ each. The Shannon-Wiener index was 1.70, evenness index of 0.29 and dominance index of 0.30 was recorded (Table 4$)$.

Maize + Cowpea (30,000 plants / ha) - M2

The sum of fifteen plants from twelve families were listed. Ageratum conyzoides dominated with the highest RIV of 33.82\% (Table 3). Brachiaria deflexa followed with a RIV of $20.18 \%$. Species with low RIV were Talinum fruticosum, and Vigna unguiculata with RIV of $0.76 \%$ each. The Shannon-Wiener index was 1.90; evenness index of 0.30 and dominance index of 0.34 were recorded (Table 4).

Maize + Cowpea (40,000 plants / ha) -M3

A total of sixteen plants from twelve families were listed. Ageratum conyzoides dominated with the highest RIV of $34.21 \%$ (Table 3). Brachiaria deflexa followed with a RIV of $18.10 \%$. Species with low RIV were Momordica charantia and Talinum fructicosum with RIV of $0.87 \%$ each. The Shannon-Wiener index was 1.58, evenness index of 0.30 and dominance index of 0.32 for the first trial (Table 4).

\section{Maize hoe - weeded control (M4)}

A total of fifteen plants from eleven families were listed. Ageratum conyzoides had the highest RIV of $35.38 \%$. Brachiaria deflexa followed with RIV $19.22 \%$. Species with low RIV were Corchorus olitorius, Dactyloctenium aegyptium and Talinum fructicosum with RIV of $0.77 \%$ each. The Shannon-Wiener index was 1.44, evenness index of 0.28 and dominance index of 0.38 (Table 4).

\section{Maize $(50,000)$ herbicide control (M5)}

A total of eleven plants from nine families were listed. Ageratum conyzoides had the highest
RIV of $36.78 \%$. Brachiaria deflexa followed with RIV of $33.46 \%$. Species with the lowest RIV were Corchorus olitorius, Dactyloctenium aegyptium and Phyllanthus amarus with RIV of $1.31 \%$ each (Table 3). The Shannon-Wiener index was 1.19, evenness index of 0.30 and dominance index of 0.39 (Table 4).

\section{Maize $(50,000)$ weedy control (M6)}

A total of nineteen plants from eleven families were listed. Brachiaria deflexa had the highest RIV of $17.30 \%$. Euphorbia deflexa followed with RIV of $15.29 \%$. Species with the lowest RIV were Indigofera hirsuta and Ludwigia decurrens with an RIV of $1.07 \%$ each (Table 3 ). The Shannon wiener index was 2.42, evenness index of 0.59 and dominance index of 0.12 (Table 4).

\section{Weed Dry Weight and Percentage Weed Reduction}

The M6 (Weedy Control) treatment accounted for the highest weed dry biomass weight, which had $126.30 \mathrm{~g}$. This was higher than all other weed biomass weight that ranged between $6.6 \mathrm{~g}$ in maize $(50,000$ plants per hectare $)+$ cowpea $(40,000$ plants per hectare) and $7.7 \mathrm{~g}$ in maize $(50,000$ plants per hectare $)+$ cowpea (40,000 plants per hectare). The reduction in weed dry weight were as follows; M1 $(20,000$ plants per hectare) treatment reduced weed by $92.32 \%$; M2 (30,000 plants per hectare) treatment reduced weeds by $93.11 \% ; 94.75 \%$ reduction was observed in M3 (40,000 plants per hectare); M4 (Maize Hoe Weeded) treatment reduced weed by $90.72 \%$; M5 (Maize Herbicide Control) treatment had weed reduction of $71.61 \%$ (Table 5). 
Table 5: Biomass accumulation of herbaceous floras on the enumerated maize plot in Ibadan, Nigeria Treatment Weed dry weight $(\mathrm{g})$ per $0.25 \mathrm{~m}^{2} \quad$ Weed Control Efficiency (\%)

\begin{tabular}{lrc}
\hline M1 & $9.7 \pm 0.7$ & 92.32 \\
M2 & $8.7 \pm 1.0$ & 93.11 \\
Maize + Cowpea $(20,000)$ & $6.6 \pm 0.7$ & 94.75 \\
Maize Hoe Weeded & $11.7 \pm 0.8$ & 90.72 \\
Maize Herbicide Control & $35.9 \pm 1.7$ & 71.61 \\
Maize Weed Control & $126.3 \pm 2.0$ & - \\
LSD (0.05) & 3.23
\end{tabular}

NOTE: $M 1=$ Maize (50,000 plants/ha) + Cowpea (20,000 plant/ha) $;$ M2 = Maize (50,000 plants/ha) + Cowpea (30,000 plant/ha); M3 = Maize (50,000 plants/ha) + Cowpea (40,000 plants /ha); M4 = Maize Herbicide Control (Maize (50,000 plants/ha); M5 = Maize Weedy Control (50,000 plants/ha); M6 $=$ Maize Hoe-Weeded (50,000 plants/ha)

\section{Discussion}

The maize + Cowpea (40,000 plants / ha) plot did better in"smothering" weeds, as the weed dry weight was less than what was obtained from other treatments. There was better land coverage in maize plots inter-planted with $V$. unguiculata which resulted in cutting off weeds from solar radiation. The shading led to a marked reduction in the ability of the weeds to photosynthesize, and hence low biomass accumulation. The lowest value of weed biomass consistently recorded in the plots of maize and $V$. unguiculata interplant, suggests smothering of weeds by cowpea. The highest weed biomass was recorded at weedy control (MWC). Weed dry weight is a vital tool to authenticate the impact of weed management on crops and their associated weeds. This agrees with the findings of Mashingaidze (2004) on maize - beans intercropping, who observed a reduction in weed dry weight by $55-66 \%$ when planted at a population of 222,000 plants/ha for beans corresponding to $33 \%$ of maize population $(37,000$ plant/ha). In a report by Bilalis et al. (2010), intercropping maize with leguminous vegetables significantly decreased weed density relative to maize monocrops. This is attributed to the reduced illumination available in maize legume intercrop for weeds. This brings about a decrease in weed density and weed dry weight when compared to mono crop. Rao (2000) claimed that a kilogram of weeds usually correlates to one kilogram of crop yield loss in the field.

In this study, the ability of $V$. unguiculata to effectively suppress weeds may have been either through interception of light from reaching the soil surface or by inhibiting weed growth by the release of allelochemicals. The laboratory analysis revealed that $V$. unguiculata has high secondary metabolite in the shoot and root (Woghiren et al., 2020). Previous studies revealed that cover crops could smother weeds either by decreasing resource accessibility (Ngouajio and Mennan, 2005) or by impairing the growth of weeds through the secretion of allelochemicals (Reberg-Horton et al., 2005). Cover crop can help to alter prevalence of weed interference by denying weeds the opportunity to use water, light, nutrients as well as soil (Ngouajio and Mennan, 2005) and the structure of weed vegetation (Wright et al., 2003). The ecosystem of soil microbes can be changed by the leftover parts of cover crops or increase microbial diversity, ensuring better soil micro-organisms predation of weeds and decreased weed seed potency (Ngouajio and McGiffen, 2002). This could also influence weed population flux (Jordan et al., 2000).

The treatment plots were dominated by species in the Asteraceae, Fabaceae and Poaceae families. The abundance of the Asteraceae and Poaceae families may be due to the fact that they are the largest families of the dicotyledons and the monocotyledons. The major weeds encountered in the treatment plot comprised all categories of weeds which are grasses, broad leaves and sedges. This findings agrees with the result of Taah et al. (2017) in which they observed the Asteraceae, Fabaceae and Poaceae families to be the most prominent families in a cassava and legume intercropping system.

\section{Conclusion}

The results of this study justify the use of Vigna unguiculata as a cover crop in maize cropping. The maize + Cowpea (40,000 plants / ha) plot did better in"smothering" of weeds, as the weed dry weight was less than what was obtained from 
other treatments. The superior performance of $V$. unguiculata at the various planting densities is an indication that the plant could be an ideal cover crop in arable agriculture.

\section{References}

Akobundu, I. O and Agyakwa, C. W. (1987). A handbook of West Africa weeds.

International Institute of Tropical Agriculture. 521 pp.

Awodoyin, R. O. and Ogunyemi, S. (2005). Use of sicklepod, Senna obtusifolia (L.) Irwin and

Berneby, as mulch interplant in cayenne pepper, Capsicum frutescens L., production. Emirates Journal of Agricultural Sciences (Al-Ain) 17(1): 10-22.

Awodoyin, R. O. and Olubode, O. S. (2009). Onfield assessment of critical period of weed interference in okra (Abelmoschus esculentus (L.) Moench) field in Ibadan, a rainforest-savanna transition eco-zone of Nigeria. Asian Journal of Food and Agro- Industry. 2009, Special issue, S288-S296.

Bilalis, D., Papastylianou, P., Konstantas, A., Patsiali, S., Karkanis, A. and. Efthimiadou, A. (2010). Weed-suppressive effects of maizelegume intercropping in organic farming. International Journal of Pest Management, 56(2): 173-181.

Hammer, O., Harper, D. A. T., and Ryan, P. D. (2001): Paleontological Statistics and Software Package for Education and Data Analysis. Palaeontologia Electronica 4(1): 9pp

IITA, (2012). International Institute of Tropical Agriculture, Maize. Croydon, CR9 3EE, UK.

Imoloame, E. O. and Omolaiye, J. O. (2017). Weed Infestation, Growth and Yield of

Maize (Zea mays L.) as Influenced by Periods of Weed Interference. Advance in Crop Science and Technology 5: 267. doi: 10.4172/23298863.1000267

Jordan, N., Zhang, J. and Huerd, S. (2000). Arbuscular - mycorrhizal fungi: Potential roles in $397-410$ weed management. Weed Research 40:

Mani, V. S., Malla, M. L., Gautam, K. C. and Bhagwndas. (1973). Weed killing chemicals in potato cultivation. 22: $17-18$.
Mashingaidze, A. B. (2004). Improving weed management and crop productivity in maize systems in Zimbabwe. Ph.D Thesis. Wageningen University, Wageningen, The Netherlands Ngouajio, M. and McGiffen, M. E. (2002). Going Organic Changes Weed Population Dynamics. HortTechnology, 12: 590 - 596.

Ngouajio, M. and Mennan, H. (2005). Weed populations and pickling cucumber (Cucumis sativus) yield under summer and winter cover crop systems. In Crop Protection 24 (6): 521 526. Doi: 10.1016/j.croppro- 2004.10.004.

Rao, V. S. (2000). Principles of Weed Science. Oxford and IBH Publishing Co. pp 7, 411 - 447.

Reberg - Horton, S. C., Burton, J. D., Danehower, D. A., Ma. G., Monks, D. W., Murphy, J. P., Ranells, N. N., Williamson, J. D. and Creamer, N. G. (2005). Changes over time in the allelochemical content of ten cultivars of rye (Secale cereal L.). Journal of Chemical Ecology 31, $179-193$.

Taah, K. J., Buah, J. N. and OgyiriAdu, E. (2017). Evaluation of spatial arrangement of legumes on weed suppression in cassava production. ARPN Journal of Agricultural and Biological Science ISSN 1990 - 6145. Vol. 12(1): 1 - 11.

Weber, J. F., Kunz, C., Peteinatos, G. G., Zikeli, S. and Gerhards, R. (2017). Weed

Control using Conventional Tillage, Reduced Tillage, No - Tillage and Cover crops in Organic Soyabean. Agriculture 7 (43). doi: 10.3390/agriculture7050043

Woghiren, A. I. and Awodoyin, R. O. (2018). Potentials of Akidi-cowpea (Vigna unguiculata cV IT84D-666) as a cover crop in weed control in maize cropping system: Response to varying light intensities in Ibadan, Nigeria. Nigeria Journal of Ecology,Vol. 17(2): 139-148. ISSN: 1116-753X

Woghiren, A. I., Awodoyin, R. O., Ekpo, E. N., Olatidoye, O. R. and Isienyi, N. C. (2020).

Allelopathic effect of cowpea (Vigna unguiculata) shoot and root aqueous extracts on germination and growth of maize in Ibadan, Nigeria. Nigerian Journal of Plant Protection, Vol. 34 (2): 121 136.

Wright, G. C., McCloskey, W. B. and Taylor, K. C. (2003). Managing Orchard Floor Vegetation in Flood Irrigated Citrus groves. HortTechnology, 13: $668-677$. 